\title{
Contextual Effect of Community Health Service on the Use of Triple Elimination Service
}

\author{
Prissy Verasita'), Uki Retno Budihastuti'2), Bhisma Murti1) \\ 1)Masters Program in Public Health, Universitas Sebelas Maret \\ 2)Department of Obstetrics and Gynecology, Dr. Moewardi Hospital, Surakarta
}

\section{ABSTRACT}

Background: Triple elimination is the elimination of transmission of HIV, syphilis, and hepatitis B from mother to child. The Prevention of Mother to Child Transmission (PMTCT) program is a comprehensive activity. The basic condition of the case is carried out because of the importance of health promotion and early detection in strategies for managing HIV, Syphilis, and Hepatitis B infections. This study aimed to analyze contextual effect of community health service on the use of triple elimination service in pregnant women.

Subjects and Method: This was a cross sectional study conducted at 25 community health centers in Sragen Regency, Central Java, from June to July 2019. A sample of 200 pregnant women was selected by stratified random sampling. The dependent variable was the use of triple elimination. The independent variables were age, perceived susceptibility, perceived seriousness, cues to action, attitude, motivation, occupation, income, and distance to health service. The data were collected by a set of questionnaire and analyzed by multilevel multiple logistic regression.

Results: The use of triple elimination increased with age $\geq 35$ years $(b=1.29 ; 95 \% \mathrm{CI}=0.37$ to 2.21 ; $\mathrm{p}=0.006)$, working outside the home $(\mathrm{b}=1.20$; $95 \% \mathrm{CI}=0.17$ to $2.23 ; \mathrm{p}=0.012$ ), income by $\geq \mathrm{Rp}$ $1,600,000(b=1.52 ; 95 \% \mathrm{CI}=0.54$ to $2.50 ; \mathrm{p}=$ o.002), perceived susceptibility ( $b=1.46 ; 95 \%$ $\mathrm{CI}=0.53$ to $2.38 ; \mathrm{p}=0.002$ ), perceived seriousness $(\mathrm{b}=1.53 ; 95 \% \mathrm{CI}=0.55$ to $2.50 ; \mathrm{p}=0.002)$, cues to action $(\mathrm{b}=1.30 ; 95 \% \mathrm{CI}=0.30$ to $2.30 ; \mathrm{p}=0.010)$, attitude $(\mathrm{b}=1.10 ; 95 \% \mathrm{CI}=0.02$ to $2.18 ; \mathrm{p}=0.046)$, and strong motivation $(\mathrm{b}=1.68 ; 95 \% \mathrm{CI}=0.66$ to 2.71; $\mathrm{p}=0.001)$. The use of triple elimination decreased by a distance $\geq 5 \mathrm{~km}(\mathrm{~b}=-1.36 ; 95 \% \mathrm{CI}=-$ 2.27 to $-0.46 ; \mathrm{p}=0.003)$. Community health center had strong contextual effect on the use of triple elimination with ICC $=22.6 \%$.

Conclusion: The use of triple elimination increases with age $\geq 35$ years, working outside the home, income by $\geq \operatorname{Rp} 1,600,000$, perceived susceptibility, perceived seriousness, cues to action, attitude, and strong motivation. The use of triple elimination decreases by a distance $\geq 5 \mathrm{~km}$. Community health center has strong contextual effect on the use of triple elimination.

Keywords: triple elimination, health belief model, theory of planned behavior

\section{Correspondence:}

Prissy Verasita. Masters Program in Public Health, Universitas Sebelas Maret. Jl. Ir. Sutami 36A, Surakarta 57126, Central Java. Email: prissyoppo@gmail.com. Mobile: +6285879-345269.

\section{Cite this as:}

Verasita P, Budihastuti UR, Murti B (2020). Contextual Effect of Community Health Service on the Use of Triple Elimination Service. J Matern Child Health. 5(1): 67-77. https://doi.org/10.26911/thejmch.2020.05.01.08

(c) (1) Journal of Maternal and Child Health is licensed under a Creative Commons Attribution-Non Commercial-Share Alike 4.o International License. 


\section{BACKGROUND}

More than 90\% infections of HIV, syphilis, and hepatitis B in children are transmitted from the mother. Consecutively, the prevalence of HIV, syphilis, and hepatitis B infections in pregnant women were $0.3 \%, 1.7 \%$, and 2.5\%. The risk of HIV transmission from mother to child was $20 \%-45 \%$, for syphilis was $69-80 \%$, and for Hepatitis B was more than 90\% (Regulation of the Minister of Health No. 52, 2017). There were 1.4 million people in 2008 that were contaminated with syphilis. The prevalence of syphilis in Indonesia is still high. The transgender population was $53 \%$, the prevalence of syphilis was $25 \%$, the commercial sex workers was $10 \%$, men who have sex with men was $9 \%$, and the injection drug use was $3 \%$.

Based on the WHO data in 2015, 24,000 women of reproductive age were contaminated with HIV, more than 9,000 pregnant women were positively contaminated with HIV each year, and more than 30\% pregnant women (3,00o pregnant women) would gave birth babies who were contaminated with HIV. The high rate of hepatitis B was caused by the low awareness of the community towards hepatitis (Mishra et al, 2017)

The number of HIV sufferers in 2015 increased by 30,935 people. The number of HIV sufferers in 2017 increased by 3,660. The number of HIV sufferers in Central Java in 2017 was 3,731 cases. The discovery of HIV cases in men was higher than in women; it was $56.52 \%$ (Central Java Health Office, 2015).

The number of AIDS sufferers cumulatively increases every year. The cumulative number of AIDS cases in 1987 to 2017 increased by 97,942 cases. Based on the cumulative HIV cases in 1987-2017, Central Java was in the fifth highest number with a cumulative number of cases by 6,612 cases (Central Java Health Office, 2015). Based on a preliminary survey conducted in April 2018, there were 16 pregnant women were positively contaminated with HIV, 12 of them had delivered. There were 4 mothers in the process of pregnancy, 3 out of 4 pregnant women were PLHA (Sragen Health Office, 2015).

During pregnancy, the pathological condition is often found. It has bad implication for the optimal development of the fetus and mother and Syphilis from mother to baby in Asia Pacific in 2018-2030. The coordinated approaches are carried out to achieve and maintain the infection elimination that is largely preventable. They are the platform of Mother Health, Maternal, Newborn and Child Health (MNCH) for planning, service delivery, monitoring, and evaluation (Ministry of Health, 2017).

Based on a preliminary study conducted by the researcher at Sragen Regency Health Office in March 2019, there were 1,785 pregnant women in Sragen Regency. There were 551 pregnant women who participated in the triple elimination service, while 1,234 people did not participate in the triple elimination service. Based on this case, the researcher wants to analyze the factors of the use of triple elimination in pregnant women.

\section{SUBJECTS AND METHOD}

\section{Study Design}

This was a cross sectional study. It was conducted at 25 community health centers in Sragen Regency, Central Java, from June to July 2019.

\section{Population and Sample}

The target population was pregnant women. The accessible population was pregnant women in Sragen Regency. This study used stratified random sampling. There were 200 patients as a sample of this study. There were 8 patients in each community health center as the study subjects.

\section{Study Variables}

The dependent variable was the use of triple elimination. The independent variables were 
age, occupation, income, attitude, distance, perceived susceptibility, perceived seriousness, cues to action, and motivation.

\section{Operational Definition of Variables}

Age was a unit of time that measured the time of living and dead in years. The data were collected by questionnaire. The measurement scale was continous, but for data analysis, it was transformed into a dichotomous, coded 1 for $\geq 35$ years and o for $<35$ years.

Occupation was something that someone did to make a living. The data were collected by questionnaire. The measurement scale was categorical, coded 1 for working outside the home and o for working at home.

Income was income per capita per month which was calculated from the average amount of income received by the patients either fixed or non-fixed income every month. It was divided by the number of family members with rupiah currency. The data were collected by questionnaire. The measurement scale was continous, but for data analysis, it was transformed into a dichotomous, coded 1 for $\geq \operatorname{Rp~1,600,000~and~code~} O$ was $<$ Rp 1,600,000.

Distance was an amount of space between one location and another location, whether it was easy or not easy to be reached, especially the easy way to reach the location of health services in kilometers. The data were collected by questionnaire. The measurement scale was continous, but for data analysis, it was transformed into a dichotomous, coded 1 for $\geq 5 \mathrm{~km}$ and $\mathrm{o}$ for $<5 \mathrm{~km}$.

Perceived Susceptibility was an individual that would evaluate the possibility of other health problems that would spread. This study used questionnaires as the measurement instrument. The measurement scale was continous, but for data analysis, it was transformed into a dichotomous, coded $1=$ strong and $\mathrm{o}=$ weak

Perceived Seriousness was an individual that considered the severity of the organic and social consequences that would occur if they let HIV/AIDS spreaded without any treatment by health practitioners. The data were collected by questionnaire. The measurement scale was continous, but for data analysis, it was transformed into a dichotomous, coded 1 was strong and code 0 was weak.

Cues to Action were a stimuli needed to trigger the decision-making process, so that the health behaviour occurred. That was the use of triple elimination service. Cues to action did not come only from outside/ external (e.g. mass media communication, personal interaction, information from health workers), but can also came from inside/internal. The data were collected by questionnaire. The measurement scale was continous, but for data analysis, it was transformed into a dichotomous, coded $1=$ existed and $\mathrm{O}=$ did not exist.

Motivation internal and external encouragement to carry out triple elimination service. The data were collected by questionnaire. The measurement scale was continous, but for data analysis, it was transformed into a dichotomous, coded $1=$ strong and $\mathrm{O}=$ weak.

Attitude was one's assessment of the triple elimination service. The data were collected by questionnaire. The measurement scale was continous, but for data analysis, it was transformed into a dichotomous, coded $1=$ positive and $\mathrm{o}=$ negative .

\section{Data Analysis}

Univariate analysis was carried out to describe the sample characteristics. Bivariate analysis was measured by chi-square test. Multivariate analysis was carried out using multilevel analysis with the Stata 13 application.

\section{Research Ethic}

Ethical clearance in this study came from the Health Research Ethics Committee of Faculty 
Verasita et al./ Contextual Effect of Community Health Service

of Medicine, Universitas Sebelas Maret, Surakarta, Number: 329/UN27.06/KEPK/EC/2019.

\section{RESULTS}

1. Univariate analysis

Table 1 shows that the result of the univariate analysis of the effect of using triple elimination service with the result of pregnant women aged $<35$ years were $90.0 \%$ and pregnant women aged $\geq 35$ years were $10.0 \%$. Pregnant women who worked outside the home were $52.5 \%$ and pregnant women who worked at home were $47.5 \%$.

Table 1. The univariate analysis of the determinant of the use of triple elimination service in pregnant women

\begin{tabular}{|c|c|c|}
\hline Variable & $\mathbf{n}$ & $\%$ \\
\hline \multicolumn{3}{|l|}{ Age } \\
\hline$<35$ years & 180 & 90.0 \\
\hline$\geq 35$ years & 20 & 10.0 \\
\hline \multicolumn{3}{|l|}{ Occupation } \\
\hline Working at home & 95 & 47.5 \\
\hline Working outside & 105 & 52.5 \\
\hline \multicolumn{3}{|l|}{ Income } \\
\hline$<\operatorname{Rp} 1,600,000$ & 61 & 30.5 \\
\hline$\geq \operatorname{Rp} 1,600,000$ & 139 & 69.5 \\
\hline \multicolumn{3}{|l|}{ Distance } \\
\hline$<5 \mathrm{~km}$ & 141 & 70.5 \\
\hline$\geq 5 \mathrm{~km}$ & 59 & 29.5 \\
\hline \multicolumn{3}{|l|}{ Perceived susceptibility } \\
\hline Weak & 42 & 21.0 \\
\hline Strong & 158 & 79.0 \\
\hline \multicolumn{3}{|l|}{ Perceived seriousness } \\
\hline Weak & 45 & 22.50 \\
\hline Strong & 155 & $77 \cdot 50$ \\
\hline \multicolumn{3}{|l|}{ Cues to action } \\
\hline No & 13 & 6.50 \\
\hline Yes & 187 & 93.50 \\
\hline \multicolumn{3}{|l|}{ Motivation } \\
\hline Weak & 31 & $15 \cdot 50$ \\
\hline Strong & 169 & 84.50 \\
\hline \multicolumn{3}{|l|}{ Attitude } \\
\hline Negative & 20 & 10.0 \\
\hline Positive & 180 & 90 \\
\hline
\end{tabular}

Pregnant women with an average income $\geq$ Rp 1,600,000 per month were 139 people (69.5\%), while pregnant women with an average income $<\operatorname{Rp} 1,600,000$ per month were 61 people (30.5\%). Pregnant women with a distance of residence to a health facility $<5$ $\mathrm{km}$ were 141 people (70.5\%), while pregnant women with a distance of residence to a health facility $\geq 5 \mathrm{~km}$ were 59 people (29.5\%). Pregnant women who had cues to action were 187 people (93.5\%), while pregnant women who did not have cues to action were 13 people (6.5\%). Pregnant women who had weak perceived seriousness were 45 people (22.5\%), while pregnant women who had strong perceived seriousness were 155 people (77.5\%).

Pregnant women who had low perceived susceptibility was $21.0 \%$, while pregnant women who had strong perceived susceptibility were 158 people (79.0\%). Pregnant women who had low motivation were 31 people (15.5), while pregnant women who had high motivation were 169 people 
Verasita et al./ Contextual Effect of Community Health Service

(84.5\%).

\section{The result of bivariate analysis}

Table 2 shows the result of the bivariate analysis, the effect between each of the independent variables (age, occupation, income, distance, perceived susceptibility, perceived seriousness, cues to action, motiva- tion, and attitude) and the dependent variable using triple elimination service.

Age affected the use of triple elimination service. Pregnant women aged $<35$ years $(76.7 \%)$ often used triple elimination service than pregnant women aged $\geq 35$ years (5.0\%) with a value $(\mathrm{OR}=3.41 ; \mathrm{p}=0.003)$.

Table 2. The bivariate analysis of the determinant of the use of triple elimination service in pregnant women

\begin{tabular}{|c|c|c|c|c|c|c|}
\hline \multirow{3}{*}{ Variables } & \multicolumn{6}{|c|}{ The use of triple elimination } \\
\hline & \multicolumn{2}{|c|}{ Yes } & \multicolumn{2}{|c|}{ No } & \multirow{2}{*}{ OR } & \multirow[b]{2}{*}{$\mathbf{p}$} \\
\hline & $\mathbf{n}$ & $\%$ & $\mathbf{n}$ & $\%$ & & \\
\hline \multicolumn{7}{|l|}{ Age } \\
\hline$<35$ years & 138 & 76.7 & 42 & 23.3 & 3.41 & 0.003 \\
\hline$\geq 35$ years & 1 & 5.0 & 19 & 95.0 & & \\
\hline \multicolumn{7}{|l|}{ Occupation } \\
\hline Working at home & 63 & 66.3 & 32 & 33.7 & 3.23 & 0.012 \\
\hline Working outsise & 76 & 72.4 & 29 & 27.6 & & \\
\hline \multicolumn{7}{|l|}{ Income } \\
\hline$<\operatorname{Rp} 1,600,000$ & 8 & 13.1 & 53 & 86.9 & 4.07 & 0.002 \\
\hline$\geq \operatorname{Rp} 1,600,000$ & 131 & 94.2 & 8 & 5.8 & & \\
\hline \multicolumn{7}{|l|}{ Distance } \\
\hline$<5 \mathrm{~km}$ & 137 & 97.1 & 4 & 2.9 & 3.74 & 0.001 \\
\hline$\geq 5 \mathrm{~km}$ & 2 & 3.4 & 57 & 96.7 & & \\
\hline \multicolumn{7}{|l|}{ Perceived susceptibility } \\
\hline Weak & $\mathrm{O}$ & $\mathrm{O}$ & 2 & 100 & 3.86 & 0.001 \\
\hline Strong & 139 & 70.2 & 59 & 29.8 & & \\
\hline \multicolumn{7}{|l|}{ Perceived seriousness } \\
\hline Weak & 1 & 2.2 & 44 & 97.8 & 4.42 & 0.001 \\
\hline Strong & 138 & 89.0 & 17 & 11 & & \\
\hline \multicolumn{7}{|l|}{ Cues to action } \\
\hline No & 1 & 7.7 & 12 & 92.3 & 3.13 & 0.008 \\
\hline Yes & 138 & 73.8 & 49 & 26.2 & & \\
\hline \multicolumn{7}{|l|}{ Attitude } \\
\hline Negative & 1 & 5 & 19 & 95 & 4.46 & 0.001 \\
\hline Positive & 138 & 76.7 & 42 & $23 \cdot 3$ & & \\
\hline \multicolumn{7}{|l|}{ Motivation } \\
\hline Weak & 1 & 3.2 & 30 & 96.8 & 2.43 & 0.061 \\
\hline Strong & 138 & 81.7 & 31 & 18.3 & & \\
\hline
\end{tabular}

Occupation affected the use of triple elimination service. Pregnant women who worked outside the home (72.4\%) often used services than pregnant women who worked at home (66.3\%) $(\mathrm{OR}=3.23 ; \mathrm{p}=0.012)$.

There was an effect of income on the use of triple elimination service. Pregnant women who had income $\geq \operatorname{Rp~1,600,000~}$ (94.2\%) used triple elimination service more than pregnant women who had $<\mathrm{Rp}$ 1,600,000 (13.1\%) (OR= 4.07; $\mathrm{p}=0.002)$.

Distance affected the use of triple elimination service. Pregnant women with a distance of residence to health services $<5 \mathrm{~km}$ (97.1\%) used triple elimination service more than pregnant women with a distance of residence to health services $\geq 5 \mathrm{~km}(3.4 \%)$ $(\mathrm{OR}=4.07 ; \mathrm{p}=0.002)$. 
Perceived susceptibility affected the use of triple elimination services. Pregnant women who had strong perceived susceptibility (70.2\%) use triple elimination services more than pregnant women who had weak perceived susceptibility ( $O R=3.86 ; \mathrm{p}=0.001)$.

The perceived seriousness affected the use of triple elimination service. Pregnant women who had strong perceived seriousness (89.0\%) use triple elimination service more than pregnant women who had weak perceived seriousness $(2.2 \%)(\mathrm{OR}=4.42 ; \mathrm{p}=$ o.001).

Cues to action affected the use of triple elimination service. Pregnant women with cues to action (73.8\%) use triple elimination service more than pregnant women without cues to action $(7.7 \%)(\mathrm{OR}=3.13 ; \mathrm{p}=0.008)$.

Attitude affected the use of triple elimination services. Pregnant women who had positive attitude $(76.7 \%)$ use triple elimination service more than those with negative attitude (23.3\%) $(\mathrm{OR}=4.46 ; \mathrm{p}=0.001)$.

Motivation affected the use of triple elimination service. Pregnant women who had strong motivation (81.7\%) use triple elimination service more than those with negative attitude $(3.2 \%)(\mathrm{OR}=2.43 ; \mathrm{p}=0.061)$.

\section{The result of multilevel multiple logistic regression analysis}

Table 3 shows the results of multivariate analysis, age, occupation, income, distance, perceived susceptibility, perceived seriousness, cues to action, motivation and attitude towards the use of triple elimination services using multilevel multiple logistic regression model. There was an effect of age on the use of triple elimination service. Pregnant women aged <35 years had logodd to use triple elimination service 1.29 units higher than pregnant women aged $\geq 35$ years $(b=1.29$; 95\% $\mathrm{CI}=0.37$ to $2.23 ; \mathrm{p}=0.022$ ).

There was an effect of occupation on the use of triple elimination service. Pregnant women who work outside had logodd to use triple elimination service 1.20 units higher than pregnant women who work at home $(b=$ 1.29; $95 \% \mathrm{CI}=0.37$ to 2.23 ; $\mathrm{p}=0.022$ ).

There was an effect of income on the use of triple elimination service. Pregnant women who had income $\geq \mathrm{Rp} 1,600,000$ had logodd to use triple elimination service 1.52 units higher than pregnant women who had income $<\operatorname{Rp~1,600,000~}(b=1.52 ; 95 \% \mathrm{CI}=$ 0.55 to $1.20 ; \mathrm{p}=0.002$ ).

There was an effect of distance on the use of triple elimination service. Pregnant women with a distance from home to health services $\geq 5 \mathrm{~km}$ had logodd to use triple elimination services 1.36 units lower than pregnant women with a distance $<5 \mathrm{~km}$ from home to health services $(b=-1.36 ; 95 ; 95 \%$ $\mathrm{CI}=-2.27$ to $-0.46 ; \mathrm{p}=0.003)$.

There was an effect of perceived susceptibility on the use of triple elimination service. Pregnant women who had strong susceptibility had logodd to use triple elimination service 1.46 units higher those with weak susceptibility $(b=1.46 ; 95 \% \mathrm{CI}=0.53$ to 2.38 ; $\mathrm{p}=0.002$ ).

There was an effect of perceived seriousness on the use of triple elimination service. Pregnant women who had strong seriousness had the logodd to use triple elimination service 1.53 units higher than pregnant women who had weak seriousness $(b=$ $0.58 ; 95 \% \mathrm{CI}=0.53$ to $2.50 ; \mathrm{p}=0.002$ ).

There was an effect of cues to action on the use of triple elimination service. Pregnant women who had cues to action have the logodd to use triple elimination service 1.30 units higher than pregnant women who had cues to action ( $b=1.30$; $95 \% \mathrm{CI}=0.31$ to 2.30; $\mathrm{p}=0.010$ ). There was an effect of motivation on the use of triple elimination services. Pregnant women who had strong motivation had logodd to use triple elimination service 1.10 units higher than pregnant women who had weak motivation $(\mathrm{b}=1.10$; CI95\% $=0.52$ to $2.18 ; \mathrm{p}=0.046$ ). 
There was an effect of attitude on the use of triple elimination service. Pregnant women who had positive attitude have the logodd to use triple elimination service 1.68 units higher than pregnant women who had weak motivation $(b=1.10$; CI95\% $=0.66$ to $2.71 ; \mathrm{p}=0.001)$.
There was a contextual effect of community health center on the use of triple elimination service with ICC 22.6\%. This means that $22.6 \%$ of the variation in the use of triple elimination was determined by variables at the community health center.

Table 3. The multilevel multiple logistic regression analysis of the determinants of the use of triple elimination in pregnant women

\begin{tabular}{|c|c|c|c|c|}
\hline \multirow{2}{*}{ Independent Variable } & \multirow{2}{*}{ b } & \multicolumn{2}{|c|}{$95 \% \mathrm{CI}$} & \multirow[b]{2}{*}{$\mathbf{p}$} \\
\hline & & Lower limit & Upper limit & \\
\hline \multicolumn{5}{|l|}{ Fixed Effect } \\
\hline Age (<35 years) & 1.29 & 0.37 & 2.21 & 0.006 \\
\hline Occupation (working outside) & 1.20 & 0.17 & 2.23 & 0.022 \\
\hline Income ( $\geq$ Rp 1,600,000) & 1.52 & 0.55 & 2.50 & 0.002 \\
\hline Distance ( $\geq 5 \mathrm{kms})$ & -1.36 & -2.27 & -0.46 & 0.003 \\
\hline Perceived susceptibility (strong) & 1.46 & 0.53 & 2.38 & 0.002 \\
\hline Perceived seriousness (strong) & 1.53 & 0.58 & 2.50 & 0.002 \\
\hline Cues to action (yes) & 1.30 & 0.31 & 2.30 & 0.010 \\
\hline Motivation (strong) & 1.10 & 0.02 & 2.18 & 0.046 \\
\hline Attitude (positive) & 1.68 & 0.66 & 2.71 & 0.001 \\
\hline \multicolumn{5}{|l|}{ Random Effect } \\
\hline $\begin{array}{l}\text { Community health centerVar } \\
\text { (Constanta) }\end{array}$ & 0.96 & & & \\
\hline $\begin{array}{l}\text { LR test vs. Logistic regression } \\
\text { ICC }\end{array}$ & $\begin{array}{l}\mathrm{p}=0.02 \\
22.6\end{array}$ & 0.21 & 4.46 & \\
\hline
\end{tabular}

\section{DISCUSSION}

1. The effect of age on the use of triple elimination health service

The results of this study indicate that pregnant women aged $<35$ years have the logodd to use triple elimination service 1.29 units higher than pregnant women aged $\geq 35$ years $(b=1.29 ; 95 \% \mathrm{CI}=0.37$ to $2.23 ; \mathrm{p}=0.022)$.

Age determines the utilization of health services related to age-specific disorders and the ability of individuals to overcome health problems. Age is one of the socio demographic factors of consumers that contribute to the utilization of health services (Wibisana, 2017). Younger ages are more open, so younger ages have demands and expectations from older ages. This is what causes younger patients to be more quickly satisfied than older ages (Schnall, 2015).

\section{The effect of occupation on the use of triple elimination health service}

The result of this study shows that pregnant women who work outside had logodd to use triple elimination service were 1.20 units higher than pregnant women who work at home $(b=1.29 ; 95 \% \mathrm{CI}=0.37$ to $2.23 ; \mathrm{p}=$ 0.022). The results of this study stated that there is an effect of occupation on the use of triple elimination health. Occupation as the best indicator of the social class of consumers, the work carried out by consumers will affect lifestyle. Subjects of the study who have work outside the home have broader insights than subjects of the study who work at home (Miniardi, 2004) 


\section{The effect of income on use of triple elimination health service}

The results showed that pregnant women who had income $\geq \operatorname{Rp} 1,600,000$ had the logodd to use triple elimination service 1.52 units higher than pregnant women who had income $<\mathrm{Rp} \mathrm{1,600,000}(\mathrm{b}=1.52$; 95\% CI= 0.55 to $1.20 ; \mathrm{p}=0.002$ ).

According to Kirilmaz (2013), patients with good incomes will be able to meet some of their needs better than those on low incomes, so people on low incomes have less expectations on health services. Therefore, someone with a high income will have high demands and expectations on health care compared to someone on a low income.

This is because someone with a high income feels financially able to meet the needs for health services. Thus, high income people tend to use their income to pay for services that are deemed to meet expectations and provide satisfaction. Whereas someone with a low income tends to depend on cheap health services so that the income he has will still be able to receive services that are considered affordable in terms of costs without more demands and expectations (Tarkang, 2015).

\section{The effect of perceived susceptibility} on the use of triple elimination health service

The results showed that pregnant women who had distance $\geq 5 \mathrm{~km}$ from home to health services have the logodd to use triple elimination service 1.36 units lower than pregnant women who have distance $<5 \mathrm{~km}$ from home to health services $<5 \mathrm{~km}(\mathrm{~b}=-1.36 ; 95 \% \mathrm{CI}=-$ 2.27 to $-0.46 ; \mathrm{p}=0.003$ ).

It is in accordance with the theory of the utility of health services which explains that one's desire to utilize health services is also determined by supporting factors, one of which is the distance or accessibility of health services. Poor road conditions and difficult access to health services make a person un- willing to take advantage of these health services. This is distinct from the theory of health belief models which stated that structural factors related to access to health services will tend to influence one's decision to use or not utilize health services. Subjects of the study who have houses far from community health center still tend to use a lot of health services because there are no other health service options (Irawan and Ainy, 2018).

\section{The effect of perceived seriousness on the use of triple elimination health service in pregnant women}

The results showed that pregnant women who had strong seriousness had the logodd to use triple elimination services 1.53 units higher than pregnant women who had weak seriousness $(b=0.58 ; 95 \% \mathrm{CI}=0.53$ to 2.50 ; $\mathrm{p}=0.002)$.

The results showed that the high perceived seriousness could increase perceived susceptibility. The results of this study are in line with Bock (2009) which stated that high risk people who utilize triple elimination feel a strong vulnerability to HIV, syphilis and hepatitis B. Vulnerability is a subjective condition so that the acceptance of individuals, especially people at high risk for susceptibility to infection with HIV, syphilis and hepatitis B can vary.

Someone might be said to have very strong susceptibility to HIV, syphilis and hepatitis B if they have the belief that they are at risk of suffering from HIV, syphilis and hepatitis $\mathrm{B}$, have friends or partners who are infected with HIV, syphilis and hepatitis B, or have a history of behavior risk for contracting HIV, syphilis and hepatitis B.

A person may be declared to have a very weak susceptibility to HIV, syphilis, and hepatitis B if they do not have the belief that they are at risk of suffering from HIV, syphilis, and hepatitis B (Sumarni, 2017). 


\section{The effect of cues to action on the use of triple elimination health service}

The results showed that pregnant women who had cues to action had logodd to use triple elimination services 1.30 units higher than pregnant women who did not have cues to action $(b=1.30 ; 95 \% \mathrm{CI}=0.31$ to $2.30 ; \mathrm{p}=$ 0.010).

High cues to action can increase the use of HIV, syphilis and hepatitis B. Cues to action is a part of the Health Belief Model which is something that drives decisions in changing behavior (Horne et al., 2013). Cues to action can come from people or events that are the reason for an individual or community to change their habits or behavior. For example, previous pain experiences or healthy individuals who are role models of someone in acting. Pregnant women who know that fellow members of their community are affected by HIV, syphilis, and hepatitis B and have received treatment from health workers will be encouraged to take advantage of HIV, syphilis and hepatitis B services (Nareswara et al., 2016).

The results of this study are in line with a study conducted by Schnall et al. (2015) which stated that more than half of the subjects of the study were never encouraged to test for HIV, syphilis and hepatitis B so that they did not use HIV, syphilis and heaptitis B. Services including action offered by health care providers (Schnall et al., 2015).

\section{The effect of motivation on the use of triple elimination health service}

The results showed that pregnant women who had strong motivation had logodd to use triple elimination services 1.10 units higher than pregnant women who had weak motivation $(b=1.10 ; 95 \% \mathrm{CI}=0.52$ to $2.18 ; \mathrm{p}=$ 0.046). Related study stated that the correlation of the effect of triple elimination and self-management on achievement motivation. The results of the study show that moti- vation as an independent variable affects triple elimination to have a positive correlation. This proves that motivation has a significant and linear effect on triple elimination. Better and higher motivation will be followed by an increase in triple elimination, and vice versa (Amir, 2016).

\section{The effect of attitudes on the use of triple elimination health service}

The results of this study indicated that pregnant women who had a positive attitude had logodd to use triple elimination service 1.68 units higher than pregnant women who had weak motivation $(b=1.10 ; 95 \% \mathrm{CI}=0.66$ to 2.71; $\mathrm{p}=0.001$ )

A good attitude about HIV, syphilis and hepatitis B services can increase the use of HIV, syphilis, and hepatitis B services. An attitude is a readiness or willingness to act. Attitude is a predisposition to the action of a behavior. A positive attitude means the tendency of actions to approach, like, and expect certain objects (Kroes, 2016). Based on a study conducted by Fauk et al. (2018) attitude is an important influence of intention (Kroes, 2016).

\section{AUTHOR CONTRIBUTION}

Prissy Verasita as the main researcher collected and processed the data. Bhisma Murti examined the conceptual framework and methodology of the stusy. Uki Retnobudihastuti checked the results of the study and writing procedures.

\section{CONFLICT OF INTEREST}

There is no conflict of interest.

\section{FUNDING AND SPONSORSHIP}

This study used personal fund from the main researcher.

\section{ACKNOWLEDGEMENT}

The researchers would like to thank 25 community health centers in Sragen who had assisted this study. 


\section{REFERENCE}

Abamecha F, Godesso A, Girma E (2013). Intention to voluntary HIV counseling and testing (VCT) among health professionals in Jimma zone, Ethiopia: The theory of planned behavior (TPB) perspective. BMC Public Health, 13(1): 1. https://doi.org/10.1186/1471-2458:13140.

Abolfotouh MA, Banimustafa AA, Mahfouz $\mathrm{AA}, \mathrm{Al}$-assiri $\mathrm{MH}$ (2015). Using the health belief model to predict breast self examination among Saudi women. BMC Public Health, 1-12. https://doi.org/10.1186/s12889-015-2510-y.

Deo KK (2015). Barriers to utilization of antenatal care services in Eastern Nepal. Public Health Policy. 3:197. https://doi.org/10.3389/fpubh.2015.0 0197

Eluwa GI, Sylvia A, Luchters S, Ahonsi B (2015). HIV Risk Perception and Risk Behaviors among Men Who Have Sex with Men in Nigeria. J of AIDS \& Clinical Research 6: 478. Retrieved from Retrieved from http://-dx.doi.org-/10.4172/2156113.1000478

Emdadi S, Hazavehie SM, Soltanian A, Bashirian S, Heidari MR (2015). Predictive factors of regular physical activity among middle-aged women in the West of Iran, Hamadan: Application of PRECEDE Model. J Res Health Sci. 15(4): 244-9.

Fauk, Nelsensius K, Sukmawati AS, Wardojo SSI, Teli M, Bere YK, Mwanri L (2018). The intention of men who have sex with men to participate in voluntary counseling and HIV testing and access free condoms in Indonesia. AJMH: 2:1557988318779737. https://doi.org/10.1177/1557988318779737.

Febres CB, Kimberly CB, Teresita RJ, Carmen FC, Sonia MM, Shira MG (2018).
Influence of peer support on hiv/sti prevention and safety amongst international migrant sex workers: A qualitative study at the mexico-guatemala border. PLoS ONE. 13(1): 1-20. https://doi.org/10.1371/journal.pone.01907 87.

Gedefaw AA (2016). Determinants of voluntary HIV counseling and testing among Addis Ababa university students, Ethiopia. Global J. 16(2).

Gholami M, Jabbari A, Kavosi, Z, Gholami, M (2016). Service Quality in Iran's Medical Tourism: Hospitals in Shiraz City. IJTMGH, 4(1): 19-24.

Kurniasari MA, Murti B, Demartoto A (2016). Association between participation in HIV/ AIDS peer group, stigma, discrimination, and quality life of people living with HIV/AIDS. JEPH. 1(2): 125-132. https://doi.org/1026911/jepublichealth.2016.01.02.06.

Lawrence W, Green Judith M, Ottoson. (2006). A framework for planning and evaluation: precede proceed evolution and application of the model. 10Es Ans J De Sante Publique: 1-4. http://www.eldis.org/vfile/upload/1/-document/o803/id2188.pdf

Murti B (2018). Prinsip dan metode riset epidemiologi ( $5^{\text {th }}$ ed.). Retrieved from https://doi.org/-978-602-71484-2-o

Nareswara A, Murad C, Afriandi I (2017). Health belief model theory application on voluntary counseling and testing among homosexual men in Bandung greater area. AMJ, 3(4): 595-604. https://doi.org/10.-15850/amj.v3n4.945 .

Obermeyer, Carla M, Michelle O (2007). The utilization of testing and counse-ling for HIV: A review of the social and behavioral evidence. AJPH. 97(10): 176274. https://doi.org/10.2105/AJPH.2006.096263. 
Peraturan Menteri Kesehatan Republik Indonesia Nomor 75. (2014). Pusat Kesehatan Masyarakat Dengan Retrieved from https://www.bps.go.id/dynamictable/2018/o5/18/1337/persentasepanjangjalantolyangberoperasimenurutoperatornya2014.html

Perdana MV, Demartoto A, Indarto D (2017). Effects of predisposing, ena-bling, and reinforcing factors on the uptake of voluntary counselling and testing among female sex workers in Grobogan, Central Java. ICPH. 172 : 243-57. Retrieved from https://doi.org/10.26911/theicph.2017.063.

Pharr JR, Nancy LL, Echezona EE (2016). Barriers to HIV testing among young men who have sex with men (MSM): Experiences from Clark County, Nevada. 8 (7):9-17. GJHSe. https://doi.org/10.5539/Gjhs.V8n7p9.

Pinar Y, Oztunc G, Zehra E, Gulsah T, Kose I (2015). An Investigation of Patients' Perceptions of Nursing Care: Case of Intensive Care. IJCS 8(2): 412.

Putri SDK, Christiani N, Nirmasari C, (2015). Hubungan Usia Ibu Hamil dengan Kepatuhan ANC di Puskesmas Suruh Kabupaten Semarang. Jurnal Keperawatan Maternitas: 33-41.

Qiao S, Yao ZH, Xiaoming L, Anitha ML (2018). Facilitators and barriers for HIV-testing in Zambia: A systematic review of multilevel factors. PLoS ONE. 1-27. https://doi.org/10.1371/-journal.pone.0192327.
Rahmadani S, Muh S, Alwy A (2014). The analysis of factors affecting the use of VCT service for high-risk group infected with HIV/ AIDS in Makassar. IJRHS. 4:1097-1104

Kementerian RI (2017). Data dan Informasi Profil Kesehatan Indonesia (Data and Information Indonesia Health Profil). Profil kesehatan Indonesia: 1-184. https://doi.org/10.1037/00223514.51.6.1173

Satwika, Pertiwi NKD, Wulandari NMK. (2018.) Pengaruh Orientasi Pasar Serta Inovasi Terhadap Keunggulan Kompetitif Dan Kinerja Bisnis. E-Jurnal Manajemen Unud, 7(3): 1481-1509. https://doi.org/10.24843/EJMUNUD.2018.v7.io3.p013.

Schnall R, Rojas M, Travers J (2015). Understanding HIV testing behaviors of minority adolescents: A health behavior model analysis. JAN in AIDS Care. 26 (3):246-258. Retrieved from https://doi.org/10.1016/j.jana.2014.08.005 .

Sumarni (2017). Analisis Implementasi Patient Safety Terkait Peningkatan Mutu Pelayanan Kesehatan di Rumah Sakit. IJNP. 5(2): 91-99. doi: http://dx.doi.org/10.21927/jnki.2017.5(2).91- 99.

Tarkang EE, Zotor FB (2015). Application of the Health Belief Model (HBM) in HIV Prevention: A Literature Review. Central African Journal of Public Health. 1(1): 1-8. https://doi.org/10.11648/J CAJPH.20-150101.11 